\title{
Justyna Miklaszewska
}

\section{Libertarian Justice}

\author{
DOI: $10.35757 /$ CIV.2009.11.10
}

The problem of justice is one of the most frequently discussed issues in the political philosophy of the latter half of the $20^{\text {th }}$ century. The ongoing discussion about the notion of justice intensified in the 1970's under the influence of the works of John Rawls. Starting with the article Justice as Fairness (1958), later in A Theory of Justice (1971) and finally in Political Liberalism (1993). ${ }^{1}$ Rawls analyzed, supplemented and modified his theory of justice which, by the author's intention, pertained to the social sphere and to the organization of the State and could thus be referred to as social or political justice. The theory of a well-ordered and just society was based on this notion of justice, and the role of this concept was to determine the principles of a just distribution of goods within the State. Hence its other name: distributive justice.

Rawls's position stood as a novelty against the traditional backdrop of liberalism, because by extending (excessively, in Robert Nozick's opinion) the State's right to exercise control over produced goods, the laissez faire principle was called into question. Rawls's Theory of Justice, published in the early 1970's, became one of the most important philosophical works of the $20^{\text {th }}$ century and, at the same time, the standard-bearing text of American

Justyna Miklaszewska - professor of philosophy and director of the History of Philosophy Department in the Institute of Philosophy at the Jagiellonian University.

1 Cf. J. Rawls: Collected Papers, ed. by S. Freeman, Harvard University Press, Cambridge 1999; idem: A Theory of Justice, Oxford Univeristy Press, Oxford 1999; idem: Political Liberalism, Columbia University Press, New York 1993. 
liberalism, widely debated and commented on worldwide. In this work Rawls does not call into question the ideal of the capitalist economy, nor the principle of private property, but does declare himself in favor of a liberalism which permits State interference in the economic sphere in the name of a specific concept of justice. He therefore leans rather towards a social-democratic vision of society. These views are coupled with a conviction about the necessity of pluralism in politics, and he is convinced that the life of the community cannot be based on any particular notion of the common good.

Besides the ample commentary which developed his ideas, Rawls's work also provoked severe criticism and polemics. An important voice in this debate was Robert Nozick's book Anarchy, State and Utopia (1974). This book, written to defend the principles of classical $19^{\text {th }}$ century liberalism, pitted a contemporary restatement of the classical liberal theses: the inviolability of private property and the principle of laissez faire in the social and economic sphere, against Rawls's theory, and provided them with a theoretical justification. In the debate with Rawls, Nozick questioned the main tenets of the theory of distributive justice, however, he did not just limit himself to criticism. His book presents an original concept of just ownership (the entitlement theory) which is in keeping with the spirit of classical liberalism. This concept takes on the role of the theory of justice in Nozick's philosophy and becomes a springboard for a critique of Rawls's theory.

Like Rawls, Nozick made use of the concepts of the state of nature and natural law, as well as the social contract, in order to transform them and to invest them with new meaning in his theory. He likewise develops the theory of justice so as to use it as a basis for his theory of the perfect State (which would be a minimal one). This would be ethically justified, because only in such a State would the ideal of justice be fulfilled. This concept can be termed libertarian justice because Nozick consistently 
proclaims and creatively renews the political theory of classical liberalism.

Both of these competing liberal theories, Rawls's and Nozick's, share a similar rationalist approach. Both philosophers start out with assumptions about human nature and from there proceed to deduce a theory of justice upon which they in turn base their vision of the perfect liberal State. For Rawls, this is a welfare State, whereas in Nozick's theory it is a State which does not interfere in economics. On the one hand, a Platonic influence with a utopian mindset can certainly be detected here. On the other hand, contemporary American society is a point of reference for both theories. However, Rawls attempts to bring this perfect, universal model of the State closer to reality and to embody it in a liberal constitutional democracy in which human rights are protected (especially in his later works), whereas Nozick adheres to the general utopian formula. An examination of his theory shows that justice cannot be reconciled with the ideal of a minimal State and that attempts to apply the principles of justice actually reveal the defects of his theoretical approach.

\section{Distributive Justice}

The concepts of state of nature and social contract are the starting point for Rawls. The origin of these concepts goes back to the Enlightenment, but in his theory they take on new meaning, receive an original connotation and fulfill a different function. Rawls's "original position" is the notion which corresponds to the state of nature. Its participants are rational beings who choose the principles of justice upon which society will be based and which will constitute the norms for their future life in this society. These people are situated behind a "veil of ignorance." They have no knowledge about their situation in the future society. Nor do they know the fate that awaits them, what position they will hold in the 
future, nor even in what capacity they will participate. They must therefore define the principles of justice without bias or prejudice, for they cannot exclude the possibility that they themselves will be among the most underprivileged.

Because these beings knowledge is so limited that they do not even know the capacities or talents they will be given, they cannot be treated as real people. Rawls does in fact point out that these are not real people but only artificial, rational constructs; beings who only have the capacity to choose a moral good. Similarly, Rawls does not consider the social contract as something real, but rather as a hypothetical situation which only serves to bring to light the principles of justice.

Rawls's original transformation of the concepts of state of nature and the social contract was received with praise, but was also the object of criticism. The hypothetical nature of his original position was attacked. The legitimacy of speculating about situations which not only had never actually existed, but which were not even possible, was called into question. Rawls responded by affirming that from the outset the situation was assumed to be hypothetical, but that it served the function of bringing to light the principles of justice which would allow for the construction of the model of the perfect and just State, and for an assessment of actual, existing regimes. ${ }^{2}$

Rawls's idea turned out to be superb, and not only because of the way in which it adopted categories borrowed from Enlightenment thinking to contemporary political thought. The concepts of the original position and the veil of ignorance which he introduced opened a new train of thought in political decision theory and in the theories of rational choice, especially regarding collective decisions. It inspired and gave new stimulus to research the possibility of unbiased and disinterested decisions. In other words, is it possible to have situations in which individuals rise above the narrowly defined economic rationality which consists

\footnotetext{
2 J. Rawls: A Theory..., pp. 24-25, 37. Cf. also: idem: Political Liberalism..., p. 28.
} 
in the maximization of personal profit, in order to make collective decisions which also take into account the interests of others? And if so, then how, and under what conditions? The notions of the veil of ignorance and the original position provide a rational justification for such choices. James M. Buchanan and David Gauthier developed this further, and tried to make the conditions for unbiased and rational collective decision-making more concrete and precise. ${ }^{3}$

Nozick was not able to perceive the uniqueness and complicated nature of collective choices. He defended a concept of rationality tied to individual choice and consisting in the maximization of personal gain or utility by the individual. While perceiving individual action according to the spirit of traditionally understood economic rationality, Nozick made use of the modern theory of natural law, and especially of John Locke's political philosophy, so as to deduce a theory of justice from these suppositions. In Nozick's approach, the theory of justice pertains only to personal property, to situations in which wealth is appropriated or transferred, and to the rectification of damages or past injustices. Nozick did not sufficiently appreciate the value and meaning of Rawls's idea. He underestimated the utopian, the "as if" character of the story about the establishment of a social contract and of the resulting discovery of two principles of justice: the principle of equal liberties for all and the principle of just inequalities if they benefit members of the most disadvantaged societal groups. He attacked this theory from an individualistic standpoint and challenged the abstract character of the assumptions made by Rawls. He reproached it for only considering the "end state" and the "current time-slice" when it came to making judgments on just property ownership, and for not considering the past and the processes which led to the present situation.

\footnotetext{
3 J.M. Buchanan, G. Tullock: The Calculus of Consent. Logical Foundations of Constitutional Democracy, The University of Michigan Press, Ann Arbor 1962; D. Gauthier: Morals by Agreement, Clarendon Press, Oxford 1986.
} 
"Historicity" was Nozick's main argument. The theory of justice in holdings he created has, in contrast to other theories, a historical character, because it calls for a consideration of the entire course of creation of property, of all of the processes from the beginning until the present moment. The history of a given object had to be carefully studied to determine whether all the processes of its acquirement or transfer were just, that is, whether they occurred without violating anyone's rights. Nozick points out that historical definitions of property existed which were nevertheless based on a pattern such as, for example, distribution of property according to moral merit. Nozick's concept of justice differs from these in that it is not based on any specific pattern of distribution, but rather allows for all types of exchanges, transactions or donations, as long as they abide by the principle of inviolability of individual rights.

Nozick focuses on the situation of original acquisition. He makes use of the Lockean "proviso" and interprets it in an original way, as the possibility of acquiring commonly used goods under condition that compensation is paid for them. In his theory, Nozick allows for the appropriation of goods which had previously been in common use, under the condition that compensation was paid to those who from then on would be denied the possibility of using those goods. In unison with Locke, Nozick excludes here cases in which individuals were deprived of goods whose lack would lead to their demise. It was therefore forbidden to appropriate for oneself the only source of potable water in a given region. In contrast to Locke, however, he rejects the theory of acquisition through work as being difficult to interpret and useless. Furthermore, he confers an indisputable character of the appropriation of an object not owned by anyone or of an object of common use (when compensated for); private property thus created could from then only change ownership through voluntary, individual transactions which did not violate the rights of the owner, and thus only as the result of an exchange, a gift or an inheritance. 
These two principles of just ownership - the principle of just acquisition and the principle of just transfer - constitute Nozick's concept of justice. From these comes a third principle: the principle of rectification of past injustices which is a necessary supplement to the previous two principles, and so Nozick adds it. Nevertheless, as he himself recognizes, it is a principle whose theoretical expression and justification is difficult. Moreover, as the end reveals, the introduction of this principle complicates and essentially destroys Nozick's theory from the inside.

\section{The Polemic between Nozick and Rawls}

In the second part of his book, Nozick elaborates an acute and detailed critique of the concept of distributive justice. It is worth mentioning some of the most serious accusations made by him.

Nozick questions the very idea of distributive justice executed by the State and describes the fundamental error of the notion of the "current time-slice" and patterned "end-state or end-result" principles. According to Nozick, distributive justice forces us to consider only one specific state, resulting from processes which, from this theory's point of view, are less important. This state is considered independently from the past and from the events which created it. Thus, the present state of ownership is considered without asking whether this state is the result of voluntary exchange or unjust plunder. "From the point of view of the historical entitlement conception of justice in holdings," he writes, "those who start afresh to complete to each according to his' treat objects as if they appeared from nowhere, out of nothing."

As Nozick sees it, when one proceeds from such a starting point, the proponent of distributive justice applies to it the just (read:

4 R. Nozick: Anarchy, State and Utopia, Basic Books, New York 1974, pp. 160. 
"his favorite") pattern of distribution and attempts to cram and order this pattern with all types of complicated goods exchange situations which take place in society. Although, according to Nozick, it is possible to introduce pattern-based distribution into society, it is not possible to maintain it for long without recourse to constant interference in the transactions taking place on the market. Therefore, maintenance of the pattern requires the constant or periodic interference of the State in economic affairs. To illustrate this point, Nozick's book provides the example of Wilt Chamberlain, a talented basketball player who becomes a millionaire by profiting from his popularity and hard work. His activity consists in working more than what the commonly accepted pattern of work obliges, and he earns more than others because he asks for additional pay when he appears in additional matches. People gladly consent to this because they desire to see him play. However, his actions are only legal in a society which does not prohibit them, that is, in an extremely laissez faire capitalist State. In a society functioning according to the principle of distributive justice, the matter would look quite different. In the model proposed by Rawls, the State will take some of the profits through taxes, whereas in a socialist State the activity of the entrepreneur would be perceived as damaging to society, for it would break up the pattern of just distribution and lead to the creation of economic and social inequality.

Thus, a State which applies the principle of distributive justice must forbid the individual actions which in themselves are neither bad nor harmful, which do not violate anyone's rights and, on the contrary, are proof of entrepreneurial and organizational capabilities of the individual. Nozick intended this argument to generally undermine the theory of distributive justice. This argument actually became most damaging to the principle of egalitarianism, and therefore to the concept of a socialist State which would impose egalitarian norms. It damaged these much more than it did Rawls's theory. In the intertwinement of liberty 
and equality achieved in Rawls's idea of distributive justice, liberty has the upper hand, while in socialism equality dominates. According to Rawls, economic values cannot be enforced at the cost of violating the rights of the individual. These restrictions do not exist in socialism. For this reason, Nozick's argument was more pertinent to the socialist State. ${ }^{5}$

Nozick also formulates this accusation in a different way. $\mathrm{He}$ states that in a society where the principles of distributive justice are followed, "they (as do most patterned principles) give each citizen an enforceable claim to some portion of the total social product; that is, to some portion of the sum total of the individually and jointly made products. (...) Each person has a claim to the activities and the products of other persons, independently of whether the other persons enter into particular relationships that give rise to these claims (...) Whether it is done through taxation on wages or on wages over a certain amount, or through seizure of profits, or through there being a big social pot so that it's not clear what's coming from where and what's going where, patterned principles of distributive justice involve appropriating the actions of other persons." Thus, "end-state and most patterned principles of distributive justice institute (partial) ownership by others of people and their actions and labor. These principles involve a shift from the classical liberals' notion of self-ownership to a notion of (partial) property rights in other people."

Here we are dealing with a violation of the classical liberal right to self-ownership, to the property which each man possesses in his own person. ${ }^{7}$ In recalling the famous Lockean expression, however, Nozick places the concept of self-ownership within the context of individual liberty and states that being the owner of my own person means that only I can exercise control over my body and my work. The popularity of this point of view was increased

\footnotetext{
5 Ibidem, pp. 163-164.

6 Ibidem, pp. 171-172.

7 Cf. J. Locke: Two Treatises of Government. Second Treatise, Cambridge University Press, Cambridge 1998.
} 
by the fact that the concept of distribution became associated with cannibalism and linked to reflection on the admissibility of transplants. These topics all sparked heated debate. Nozick suggested that contemporary theories of justice do not protect the individual from slavery, from being controlled by someone (the State or a doctor) at will. The Rawlsian principle of maximizing the life perspectives of the poorest members of society can, according to Nozick, lead to instances of distribution of people's bodies if the right of the individual to self-ownership is not guaranteed by the State.

Even if we agree that guaranteed right to self-ownership is necessary, a problem still remains: How to pass from self-ownership to the ownership of external goods? One of the ways for justifying this step is by invoking the capabilities and talents of the individual. These talents allow the individual to transform natural resources into valuable products, which then justly belong to him. This type of argument can be found not only in Nozick's work, but also in Gerald A. Cohen and Michael Sandel. ${ }^{8}$ Rawls thinks differently. In his opinion, talents and capabilities are to be viewed as arbitrarily distributed among the members of society. Therefore, society has a right to distribute created goods according to its accepted principles of justice. This allocation of goods can occur, for example, through taxes levied by the State. For Nozick, however, taxes are an expression of slavery imposed by the State upon the individual, and the person who is forced to pay them finds himself in a state of coercion similar to that described by Marx when he spoke of the slavery imposed upon the worker by the capitalist. A proportional income tax is morally equivalent to forced labor. From here, the accusation that a State abiding by the distributive principle is actually following feudal

\footnotetext{
8 G.A. Cohen: Self-Ownership, World-Ownership and Equality, part I, in: F.S. Lucash (ed.): Justice and Equality, Here and Now, Cornell University Press, Ithaca 1986; part II, in: "Social Philosophy and Policy" 1986, vol. 3, no. 2; M. Sandel: Liberalism and the Limits of Justice, Cambridge University Press, Cambridge 1982.
} 
practices is but a step away. Thus, in Nozick's opinion, both the socialist and the modern liberal welfare States essentially push us back to the age of feudalism. Socialism forces individuals to work according to an inflexible egalitarian model, whereas the welfare State collects taxes which in effect amount to the extraction of a certain sum of working hours from individual. Taxes are therefore similar to feudal serfdom.

In Nozick's conception, this critique is always levelled from the vantage point of individual liberty and the protection of its fundamental rights. This is why Nozick strongly attacks the principle of "equal opportunity," which is to be observed in a State aspiring to embody the principle of distributive justice. In practice, the application of this principle leads to injustice: the situation of people who find themselves in a less-advantaged material situation is improved by taking wealth from persons who are better off. In Nozick's opinion, the only morally acceptable means of improving the living situation of the poor is philanthropy and voluntary charitable action. Thus, Nozick invokes personal rights which are individual in nature: they are the special rights of individuals to possess certain things. There is no room here for the right to exist in certain material conditions or for a social minimum.

Apparently similar views about justice are held by Friedrich A. von Hayek. Hayek makes reference to the Aristotelian distinction between commutative and distributive justice. In Aristotle's philosophy these two concepts were applied to, and could be used simultaneously in different spheres of one and the same society. Today, however, we see that these two principles are not mutually reconcilable. They constitute two different types of society, which follow different procedures for the distribution of goods. ${ }^{9}$ Hayek positions himself in favor of the concept of commutative justice, which is tied to the unhampered functioning of the free market, and against distributive justice, which leads to socialism.

9 Cf. W. Sadurski: Neoliberalny system wartości politycznych [The Neo-liberal System of Political Values], Warszawa 1980, pp. 208-209. 
Commutative justice signifies compensation according to the value which the services of a given individual have for the group of people for whom the services are rendered. This value is expressed in the price which these persons are willing to pay. The value is linked to neither the moral merits of the individual, nor to his needs. The concepts of merit or need are only taken into account when determining the principles of distributive justice in some form of socialism. Hayek's concept of justice is tantamount to free competition mechanisms and is not an ethical concept. It leads him to reject the active role of the State and its interference aimed at attenuating inequalities of wealth or at eliminating poverty.

According to Nozick, Hayek's line of thought against the concept of distributive justice is self-contradictory. In The Constitution of Liberty Hayek states that he opposes the imposition of any pattern of distributive justice on society, regardless of whether it ensured an order of equality or inequality. On the other hand, however, Hayek himself recommends a pattern which he believes is justified. In his theory, distribution in a free society should take place in accordance with a perceived value which is created for others by the works and services of a given individual. Nozick believes that this pattern can be expressed by the following maxim: "To each according to how much he benefits others who have the resources for benefiting those who benefit them." 10 Like all patterns, this one cannot be maintained in the long run. Moreover, Nozick notes that this distribution according to the benefits to others, though being the main principle behind the processes of exchange which occur in a capitalist society, does not represent the only method for a just distribution, but lies rather within the realm of Nozick's proposed system of rights, together with principles such as inheritance, donations and charitable actions.

Nozick points out that his own concept of justice is different from Hayek's because of its "historicity." In fact, despite their

${ }^{10}$ R. Nozick: op. cit., p. 158. 
apparent similarity, the two approaches are diametrically opposed. The evolutionism which lies at the basis of Hayekian thought is something different from the historicity introduced by Nozick. Hayek believes in the wisdom of institutions which arise spontaneously and possess age-old traditions. ${ }^{11}$ Nozick, on the other hand, by introducing the category of historicity into the definition of just ownership, requires a review of the historical process to analyze the aspect of justice. The sole fact that something exists and has a long-standing tradition is not an argument for him. In accusing Hayek of proposing a "patterned" concept of justice, Nozick, paradoxically, moves closer to the concept of distributive justice than Hayek himself. ${ }^{12}$

\section{A Critique of the Entitlement Theory}

Nozick brings full expression to a libertarianism in which justice is constrained to the principle of just ownership of goods, and which is presented as the Entitlement Theory composed of three principles: justice in acquisition, justice in transfer and justice in rectification of past injustices. In fact, the third principle was the one Nozick most weakly developed. In dealing with this principle, Nozick himself presents a series of doubts, and writes that he neither knows nor is able to provide a solid theoretical base for the mechanism of the rectification of damages: "If past injustice has shaped present holdings in various ways, some identifiable and some not, what now, if anything, ought to be done to rectify these injustices? What obligations do the performers of injustice have toward those whose position is worse than it would have been had the injustice not been done? Or, than it would have been had compensation been paid promptly? How, if at all, do things

\footnotetext{
${ }^{11}$ M. Kuniński: Wiedza, etyka i polityka $w$ myśli F.A. von Hayeka [Knowledge, Ethics and Politics in the Thought of F.A. von Hayek], Krakow 1999, p. 170.

${ }^{12}$ F.A. Hayek: The Atavism of Social Justice, in: idem: New Studies in Philosophy, Politics, Economics and the History of Ideas, The University of Chicago Press, Chicago 1987.
} 
change if the beneficiaries and those made worse off are not the direct parties in the act of injustice, but, for example, their descendants? Is an injustice done to someone whose holding was itself based upon an unrectified injustice? How far back must one go in wiping clean the historical slate of injustices? What may victims of injustice permissibly do in order to rectify the injustices being done to them, including the many injustices done by persons acting through their government? I do not know of a thorough or theoretically sophisticated treatment of such issues." ${ }^{13}$

Nevertheless, the proponents of libertarian justice most often invoke this very principle of rectification of damages and of injustices committed in the past. They demand the return of goods appropriated in violation of the first and second principle, and a payment of just compensation. However, this leads to many problems which are difficult to resolve. The dangerous practical consequences of this principle of justice have often been pointed out. One can imagine that an attempt to introduce it into an already existing society (for example, that of the U.S.) would lead to that state's total destruction.

Nevertheless, another case is worthy of our consideration: the case when utopian actions are not taken, and a libertarian theory of justice is not imposed on society from above, but is rather acknowledged in its universal, "natural" (in the the Kantian sense), supra-State and supra-national status. In the name of libertarian justice thus conceived, individuals living in a contemporary liberal-democratic state could demand that the State rectify injustices which they had suffered in other countries or regimes in the past.

An example of this was recently provided by the claims made by Americans of Jewish origin against Poland. They demanded the restitution of goods which had been taken from them by the Germans during the Second World War, and later nationalized

\footnotetext{
${ }^{13}$ R. Nozick: op. cit., p.152.
} 
by the socialist Polish government. They also demanded compensation for benefits derived by the national government from the use of these goods during the post-war period.

These claims, brought by the group of American Jews from Chicago and New York, were rejected by a United States court. However, legal considerations differ from philosophical problems. From a philosophical point of view, the motivation which the American court presented for rejecting the claim is rather uninteresting, whereas the argumentation contained in the claim brought by the American citizens of Jewish descent is of much greater importance. ${ }^{14}$ These claimants base their argument on an idea of libertarian justice similar to Nozick's. Their conception of the State is as a sort of protective agency which has a monopoly on providing these types of services in a given territory (in accordance with Nozick's definition). They treat the American government in this way, and demand that their protective agency exact the goods which rightly belong to them from individuals who are citizens of other countries; in other words, who are under the protection of another protective agency functioning in another territory.

However, Nozick does not at all consider this problem in reference to already existing states. He argues that the nature of protective services is such that some agency must obtain a monopoly over the provision of such services in a given territory, and that this agency subsequently becomes the State. It must be a dominating agency and cannot tolerate attempts by any individuals or groups to exact justice on their own. However, the authority of the agency extends only to the region, the territory, in which the agency is capable of enforcing its decisions. This is why, as Nozick notes, such agencies should not want to engage themselves in the disputes of their subordinates with subjects who belong to other agencies, because the consequence of such action would be war. ${ }^{15}$

${ }^{14}$ Cf. "Gazeta Wyborcza", 3, 4, 5 August 1999.

${ }^{15}$ R. Nozick: op. cit., p. 15. 
This example makes evident the defects and weaknesses of Nozick's concept of justice. The State (agency) is treated here as if it were an individual subject. Consequently, a state can also be brought to court. Furthermore, individuals appeal here to the State's unjust appropriation of property and demand compensation without consideration for the details and circumstances of those events. There is an evident lack of a theory of compensation to determine, how much indemnity is due, in which cases, and to whom.

Nozick does not take inter-state relations into account in the process of justly determining the question of property. He does not take into account ties between states. He treats the individual-state relation as if it were occurring in one state and does not see the complex situations of emigration and of changes in property law which arise from changes of place of residence. Nozick stresses the fact that history is essential in determining just property laws, but he does not notice other important circumstances.

His definition of State declares that a state functions within a given territory, and that its authority reaches as far as it is capable of enforcing its decisions. However, Nozick does not see that this definition contradicts his theory of justice. This is because Nozick's notion of justice is based on the natural rights of individuals, that is, on rights which belong to everyone and are universally binding. Therefore, justice in Nozick's vision has a universal character, whereas the State does not. The minimal State as a protective agency has been relegated to a territory and to concrete, historical circumstances.

The question arises: can one protective agency, in the name of universal individual rights, force another protective agency to pay compensation and make amends to its subjects? Nozick does not resolve this problem, and actually does not even consider it. $\mathrm{He}$ does write about the center of the agency's authority and about its periphery, but this pertains to the process of the state's formation as a monopolistic protective agency, and not to the question of 
relations between states already in existence. Therefore, this example reveals the essential flaws in the libertarian concept of justice and in its relation to the theory of the State. The minimal State as a protective agency cannot enforce certain claims of individuals who are under its protection, and is therefore not a state. Thus, Nozick's definition of a minimal State as a monopolistic protective agency turns out to be self-contradictory.

An apparently simpler problem can also be considered: namely the restitution of property appropriated by the Polish government from citizens after 1945. Today, after over 50 years, buildings and lands are being returned within the scope of reprivatization, but not to the owners themselves; rather to their relatives or to people who have bought the assets, or have in some other manner acquired the property rights during this period. This means that goods are taken away without compensation from their current users, who, at some point in the past, had received them not by some illegal act of plunder, but according to law, from the socialist government. The present capitalist state restitutes something which is not no one's, but which must be taken from someone. This situation does not seem to be just. If Nozick's theory were to be applied here, one would have to additionally ask whether these goods rightfully belonged to their owners before 1945, and whether before that some sort of injustice or abuse had not been committed, for example in the $19^{\text {th }}$ century? Every country's history contains instances of confiscation executed by the state, and of arbitrary bestowment of property. Why should 1945 represent some form of a caesura? Only because it is a symbolic date, relatively recent, and because each step further back in time becomes less precise and would bring more confusion to the question of property rights?

The principle of rectification of injustices is the weakest link in Nozick's theory of justice. Careful analysis shows that this theory is not historical at all, but that it is rather an attempt at rationalizing the basic tenet of classical liberalism, which is the 
absolute character of private property. Essentially, it attempts to use the language of contemporary political theory to make a rational justification of a classical definition of property consisting in the exclusive use and total control of a thing.

However, today's definition of property tends to be more abstract, and is thought of as the right to administer a thing, taken into consideration apart from the thing itself. The role of the legal system is based on this approach, in which relations between individuals are considered instead of considering the relation between the individual and the thing. Perhaps matters become more arbitrary here, but this approach permits us to assess a state on the way in which it approaches the right to administer objects. Does it respect this right? Does it change or violate it, and to what degree? But even here the principle of rectification cannot be justified. Every step back in time signifies the violation of someone's acquired rights. It is difficult to take back rights once they have been conferred, and this cannot be accomplished justly based upon Nozick's theory. Another libertarian philosopher who considered this matter, James M. Buchanan, proposes that we accept the status quo as the starting point for further transformations. In his opinion, just transformations of property rights can only be accomplished with the approval of both parties. Therefore, those who will benefit from a given change in property rights should pay compensation to those who will lose rights they had previously enjoyed. ${ }^{16}$ Here, however, the State becomes an administrator of property rights, as in Rawls's theory. Thus, Buchanan's solution to this problem is closer to Rawls's notion of justice than to Nozick's.

Jeremy Waldron, the author of The Right to Private Property, provides an example in his book which seemed totally implausible at the moment when it was written: the Soviet Union which undergoes a fundamental change of regime after 150 years of

${ }^{16}$ J.M. Buchanan: The Limits of Liberty: Between Anarchy and Leviathan, The University of Chicago Press, Chicago 1975. 
communism. Assuming that private property existed there before communism, the libertarian theory of justice would require for this system be returned in keeping with the principle of rectification of the damages and injustices committed over the years: assets should be returned to the descendents of the former owners and losses should be rectified. However, it would be practically impossible to judge what the exact present situation of the country would be, had communism never been introduced. ${ }^{17}$ In this situation, according to Waldron, Nozick's principle of rectification of injustices would allow for the redistribution of goods even based upon the concept of equality or social justice. This example shows that when there is no tradition-based system of individual rights, Nozick's theory essentially does not provide any reason for a society to adopt a libertarian system of private property.

Thus, Rawlsian theory of justice appears to be more consistent and better constructed that Nozickean theory because it focuses on the situation of beginning the construction of a certain model of the State - the constitutional liberal democracy - anew, and justifies its moral righteousness.

Translated by Paweł Janowski

First edition: Sprawiedliwość libertariańska, "Civitas. Studia z Filozofii Polityki" 2000, vol. 4, pp. 99-117.

${ }_{17}$ J. Waldron: The Right to Private Property, Clarendon Press, Oxford, 1988, pp. 288-289. 